Original research article

\title{
Civil Society and the Rise of the Radical Right in Poland
}

\author{
TIHOMIR CIPEK, STJEPAN LACKOVIĆ \\ Faculty of Political Sciences, University of Zagreb
}

\begin{abstract}
Summary
The influence of the radical right in the whole of Central Europe not only continues to grow, but has reached its apex by gaining power in Poland and Hungary. Its success is often attributed to two factors: a) the weakness of civil society, and b) economic and social crisis. We shall try to dispute these theses by using the example of Poland. We will defend a thesis that contradicts the usual claim that developed civil society also fosters democracy, and will show that the radical right owes its success precisely to its strength in civil society. This text will also show that there is no direct connection between the radical right and economic crisis, and that the real reason for its success is the dominance over the public discourse. The text is divided into three parts: the first will define the concept of the radical right and give an overview of the theories about its rise; the second part will focus on different explanations of the relationship between civil society and liberal democracy; and the third part will discuss the characteristics and activities of the most important organisations of the Polish radical right and their place in civil society and politics.
\end{abstract}

Keywords: Radical Right, Civil Society, Poland, Gender, Catholic Church

\section{The Radical Right}

The radical right includes those political parties or social movements that strive towards a thorough change of the institutions of the liberal-democratic political order, with the declared goal of strengthening their own nation and state. In this endeavour, they use nationalist and chauvinist politics. The nucleus of the radical-right ideology is the perceived need to build a fully homogeneous "idealised people's community", "Volksgemeinschaft" (Hillmann, 2007: 734). Right-wing radicals advocate equality and social rights, but only for members of their own national community. This idea is built on the "ethnocultural concept" of the nation through which they emphasise the cultural superiority of their own nation (Koopmans and Statham, 
1999). Their main enemy has traditionally been the left, while today it is primarily liberalism and the "pluralistic-permissive society" (Hillmann, 2007: 734). They find liberalism unacceptable because of its emphasis on the universal human rights. Radical right-wingers juxtapose individual freedoms with hierarchy and a strong authority. They do this because they think that the unity of a national community can be ensured solely through a clear social hierarchy and authority. In this need for order and hierarchy, their role models are the pre-democratic forms of government, usually absolute monarchy or some other type of authoritarian dictatorship. That is why the right in Poland and Hungary has great respect for the interwar authoritarian nationalist dictatorships ${ }^{1}$ - the dictatorship of Józef Piłsudski in Poland, and Miklós Horthy in Hungary. What is interesting is that these dictatorships included multiparty parliamentary and local elections, but the liberal elements of the system - meaning those that are supposed to protect individual freedoms, such as an independent judiciary and the tripartite division of power - were suspended. The executive power could therefore act completely arbitrarily. There is no doubt that these are predecessors of the system that Viktor Orban (2014) called "illiberal democracies". His statement was directed against the liberal elements of democracy, but not democracy itself. In other words, the radical right questions the values of liberalism and tripartite division of power, or rather the statutory constraints imposed on the people's sovereignty (Mudde, 2010: 1168-1169). Today, due to the dominance of the democratic public discourse, the "pressure" of their own democratic states' institutions, and the context of the European Union and the law, the nationalist right of the Orban type as well as the more radical ones accept the rules of democracy. There is a clear difference here between the extreme right, neo-fascism and the radical right. The extreme right does not accept democracy and its institutions, while the radical right uses democratic institutions to gain strength and power while claiming that it is the only true representative of the voice of the people (Mudde, 2007: 49). In other words, it claims to understand and advocate real democracy. It should also be noted that the radical right is not the same as the conservative, populist right. Namely, populists and conservatives undoubtedly accept basic liberal values because they consider them to be fundamental values of the modern age and the western civilisation (Hillmann, 2007: 734). In short, the radical right is "a half-way house towards extremism", but it is not extreme (Eatwell, 1996: 307). Or, as Zgurić (2014) put it, the extreme right is undemocratic and often elitist, while the populist, i.e. radical right at least declares itself as democratic. Moreover, the central premise of the radical-right ideology is that they represent the people, implying that anyone who does not represent radically-right ideas is actually the enemy of the people. Politics is thus reduced to a friend-enemy relationship that questions the possibility of reaching a

${ }^{1}$ For more on interwar authoritarian dictatorships in Central Europe, see Oberländer (2017). 
compromise, as compromising represents the very essence of democratic politics. In that sense, the radical right ravages the essence of democracy. It should therefore be concluded that the radical right is not just a right-wing continuation of conservative politics nor a new fascism, but a new political phenomenon that cannot be explained solely through traditional political fissures: conservative - modern, lay - religious, rural - urban, work - capital (Minkenberg, 2000). In the centre of radical-right politics lies ethnocentrism, which is based on emphasising the specificity and superiority of a particular national culture. We should not look for proponents of the radical right only among the "losers of transition", but also among people searching for a safe foothold in the midst of insecurities caused by the rapid changes of globalisation. They find safety in national identity. These are the people that disdain the Other, feeling that foreigners endanger their national identity and the material wealth of their nation. Namely, in the centre of the radical-right ideology lies the myth of the homogeneous nation. It is characteristic of a type of nationalism that starts from the romantic notion of a nation as a single body, significantly determined by its language which is a reflection of the people's soul and, consequently, a single national culture. This is an understanding of the nation that places it somewhere "between the poles of demos and ethnos" (ibid.). Similarly, one could say that the radical right moves between two shores, fascist and conservative, landing now on one, now on the other because it simply cannot sail in the middle of the river (Ziegler, 2018). It is therefore clear that its anti-Enlightenment and nationalism sometimes take on fascist characteristics, but this is not a political position that wants to destroy democratic institutions completely. It should thus be repeated that the radical right wants democracy only for members of its own nation and that it rejects liberal elements of the contemporary Western political order. To put it systematically, ideologies and politics of the radical right have the following characteristics: a) predominance of the collective (nation, state) over the individual - contrary to the liberal democratic emphasis on the significance of individual's inviolable rights; b) anti-pluralism - state and society should be homogeneous, and minorities always represent a disruptive factor; c) anti-parliamentarianism - the reduction of politics to the friend-enemy relationship; d) an authoritative state that guards the homogeneous nation from liberal individualism and the philosophy of universal human rights - which exist only for members of their own nation; and e) this is often accompanied by historical revisionism and antisemitism, which deny or relativize fascist crimes and propagate conspiracy theories of a Jewish world government; recently, there is also f) an intolerance towards Islam; and, finally, g) an emphasis on the importance of "meta-politics", which they would use to control a specific discourse and thus win the "hearts of people" and ensure the cultural hegemony of the right. ${ }^{2}$

2 The analysis of the importance of "meta-politics" in radical-right ideology was done by Wei $\beta$ (2017). 
If we apply this definition of the radical right to the circumstances in Poland, we can see that the Polish right has all those characteristics and that its ideology centres on ethno-nationalism, Catholic fundamentalism and anti-communism. It is precisely this anti-communism that distinguishes it from the West-European right. Namely, in the West, anti-communism became less important after the collapse of communist dictatorships, when the main enemy of the radical right became "decadent" liberalism (Weiß, 2017: 21). So, in Poland we are witness to the phenomenon of anti-communism without any communists, which is also widespread in Croatia. This is an issue of liberal values being proclaimed as some kind of leftovers from communism. Similar ideas are also advocated by the Croatian radical right (Cipek, 2017).

It should be concluded that there are people in every society that share the values of the radical right, which is why this political position represents the "normal pathology" of every society (Scheuch and Klingeman, 1967). However, the real question is under what conditions does this "normal pathology" turn into social movements? Discontent is present everywhere, but right-wing protest movements and organisations are not.

\section{Mobilisation of the Radical Right}

As was already said, there is no doubt that every society includes social strata that feel like they belong to a completely homogeneous nation, but not every society has an organised radical right. The question which should therefore be asked is which structural social conditions must always be met in order for the radical-right discourse to become influential in public and for right-wing social movements and organisations to be formed. Didn't the success of the Polish right result from its entry into civil society and the acceptance of its topics in public? This text will not thematise right-wing political parties and movements, but instead will focus on radically-right groups. These groups can be structured as civil society organisations, which means they act independently of political parties or social movements. The isolation from the Others strengthens the homogeneity within the group as well as the belief of its members in their own righteousness. These are often organisations that are more extreme than radical-right groups, and which can even resort to violence in their actions. Namely, it is precisely such social groups and associations that represent the "micromobilisational potential" of the radical right (Bergmann, 1994; Minkenberg, 2015). In this text, we are interested in the ideology of the radical right that has been formed in civil organisations in Polish society.

The rise of the radical right in Poland can be interpreted by using the "grievance theory" or the "opportunity structure theory". The "grievance theory" explains the rise of the right by the intensification of social problems, economic crisis 
and a corresponding rise in unemployment (Lipset and Raab, 1970). A good example of this interpretation as applied to Polish circumstances is the work of David Ost (2006). According to him, Polish society was broken and has turned radically towards the right because social democrats, inspired by the "third way" of the British Labour party, accepted neoliberal social politics that killed social equality and justice. The focus of the "grievance theory" is the claim that the radical right emerges in the absence of the left. This may seem self-evident at first, but Platek and Plucienniczak (2017) are right to claim that the "grievance theory" cannot explain why the rise of the radical right did not happen in the first ten years of transition. This was a time of great social breakdown, when mass discontent rolled through the streets, but did not lead to the formation of a significant radical right (ibid.: 291). Their conclusion is that the years of great social upheavals in Poland passed without right-wing mobilisation. That is why they think that a better explanation for the rise of the radical right in Poland can be provided by the "opportunity structure theory". They pointed out that this theory was successfully applied by Rafał Pankowski (2010), who demonstrated that the rise of the radical right in Poland was not the result of the economic crisis, but their ability to become part of civil society and to impose their topics in public (according to Platek and Plucienniczak, 2017: 292). Of course, the rise of the radical right also depends on the structural-institutional conditions in the political system in the narrow sense of the term, but the analysis of this paper is focused on the relationship between the radical right, its discourse and its place in civil society. As for those theories that interpret the mobilisation of the radical right in Poland, we think that the explanation which combines both approaches is the closest to the truth. However, this text will not include the analysis of social movement theories and their appropriateness for Polish circumstances, because this is not our area of expertise. It seems more appropriate to try to explain the connection between civil society and the radical right. Namely, our position is that right-wing topics would not be accepted among the Polish public if the radical right did not possess an understanding of what a part of the right-wing oriented public wants to hear. In order to gain those insights, the right needs to take part in that society. It must enter civil society. This focus raises the question, how did the Polish right-wing radicals manage to accomplish this task? Is civil society thought to be reserved for liberal-left-wing organisations?

\section{Is There Such a Thing as Right-Wing Civil Society?}

The answer to this question depends on the definition of civil society. The normative definition of civil society reflects the claim that civil engagement can build social capital, trust, which can be transferred to the political sphere and in that way help to preserve the togetherness of a society (Putnam et al., 1994). On the other hand, it should be emphasised that today's civil society is witnessing the emer- 
gence of organisations that not only do not contribute to the formation of common liberal-democratic values, but actively attack them through their politics. Some scientists call these radically-right organisations "uncivil society", because they do not respect the values of liberal-democratic order and do not show any responsibility towards those members of the society who do not share their values (Bežovan and Matančević, 2017). But, are not such organisations also part of civil society? We agree with the political scientist Cas Mudde (2003), who pointed out that the radically-right political movements of post-communist Europe "should be included in the research of civil society". We will therefore thematise radically-right organisations as an integral part of civil society. Moreover, starting from the sociological research done by Virág Molnár (2016), we will try to show that developed civil society does not necessarily need to contribute to the strengthening of liberal-democratic institutions. In fact, the opposite can happen: a strong civil society actually weakens liberal-democratic institutions and, at the same time, strengthens the politics of the radical right. Namely, the strength of liberal democracy is based on its political institutions, not civil society. Moreover, it is not just the case that civil society cannot replace state institutions, it can dissolve them.

The relationship between civil society and democracy can be interpreted in different ways. The liberal approach emphasises the connection between civil society and democracy. This approach is based on the classic theories of Alexis De Tocqueville and Robert D. Putnam. It is thought that developed civil society strengthens social capital and trust among citizens. Civil society organisations are thought of as intermediaries between the state, the market and the individual that ensure individuals' autonomous area of activity. It is stressed that civil society represents a space in which deliberation, based on rational discussion, leads to the formation of liberal and democratic values, and in which experience of democratic behaviour can be gained. ${ }^{3}$ The main space for deliberation is a public, rational discussion in which everyone listens carefully to each other and exchanges arguments. In this liberal perspective, the growth and consolidation of civil society organisations undoubtedly strengthen democratic institutions.

The second approach begins with the theory of social movements. It advocates a thesis that the weakening of civil society in Central Europe led to the crisis of liberal democracy. Rupnik (2007) thinks that the rise of right-wing populism in Central and Southeast Europe was caused by the strengthening of legal forms and institutions, as well as by economic neoliberalism which negated the need for civic participation in democratic processes. He notes that, after the establishment of the

${ }^{3}$ Berto Šalaj's research on Croatian civil society (2012) called Putnam's thesis into question. It has been shown that activists from civil society organisations do not think this helped them to better understand and take part in democratic institutions. 
democratic order, citizens' civic engagements began to decline. A theory that follows his line of thought states that the state has once again suppressed the activities of civil society; however, Molnár (2016: 168) claims the opposite, that the split between the state and civil society actually decreased because political power shifted to the media, religious and cultural organisations, homeland associations and unions. In other words, civil society organisations substituted the function of government institutions.

The third approach starts from the premise that, in circumstances defined by weak political institutions, the activity of numerous civil society organisations can "actually lead to social fragmentation, political radicalisation and the triumph of illiberal politics" (ibid.). This is an expression of the scepticism towards Tocqueville's theory, or rather its interpretations, as well as Robert Putnam's theory on social capital (Armony, 2004). This sceptical approach is based on the results of historiographic research of social conditions in Europe between the two World Wars. Was not the Weimar Republic destroyed because it had weak democratic institutions, but very numerous and active civil associations? Did not all those associations of students, war veterans, women and youth, homeland associations, associations of lawyers, pensioners, accountants, etc. fragment Weimar's society to the extent that it became impossible to reach a consensus on the basic values of the political order? German social historian Hans-Ulrich Wehler (2003) points to the existence of numerous civil society organisations which hindered the consolidation of Weimar's democracy and prompted the rise of Nazism. The same thesis is even more strongly advocated by Sheri Berman (1997). Did not the associations of farmers, women, various cultural organisations and associations of different professions, always with a clear national character, prevent the consolidation of political order in the Kingdom of SHS/Yugoslavia? Of course, this was mainly caused by centralism, neglecting the Croatian and other national issues, and the dominance of the Serbian court. However, even when there were attempts to resolve the Croatian national question, an association of intellectuals organised around the Serbian Club or a Chetnik association would raise their voice in stern opposition (Boban, 1974). Sociologist Virág Molnár (2016) also points to the research conducted by Dylan Riley (2010), which showed that strong civil society organisations, in circumstances characterised by weak political parties in northern and central Italy, brought Fascists to power. Molnár (2016) further draws attention to the book by Mária Kovács (1994), which discussed the role of associations of classical liberal free professions, such as lawyers, engineers and doctors, in the formation of anti-liberal ideas and the rise of right-wing radicalism. In a word, by assuming Gramsci's theory of cultural hegemony, radical-right civil associations can impose their topics and thus try to become a social hegemon. ${ }^{4}$

4 On the issue of Gramsci's theory, see the latest research by Igor Lukšič and Marko Hočevar (2018). 
Connected with the current situation in Poland, the premise that civil society undermines the development and stability of liberal democracy can be contested by the claim that Polish civil society is very weak as it is. However, this claim has been effectively disputed by Anna Giza-Poleszczuk (2017). She shows that the premise of a weak civil society in Poland rests on erroneous definitions and models that start from the wrong perception of reality because the concept of civil society is strictly tied to liberalism, and only liberal organisations are counted as part of civil society. Her clear arguments disputed the premise of a weak Polish civil society, stating that the number of civil society organisations in Poland after 1989 rose by $400 \%$ in just the first five years (ibid.: 71). In order to prove that Polish civil society is actually strong, she cites mass demonstrations against the ACTA trade agreement, to which we would also add the 2017 mass demonstration for women's rights. Giza-Poleszczuk further gives an example of the emergence of urban activism, the re-awakening of rural women's associations and the mobilisation of radical-right groups and associations. All of this points to the conclusion that Polish civil society is strong, just not liberally-oriented. Research conducted by Platek and Plucienniczak (2017) for the period between 1989 and 2013 shows that right-wing radicals were attacking: a) established politicians, b) international institutions, and c) ethnic and sexual minorities. Based on the targets of their attacks, the radical right was christened the " "uncivil' part of society" (ibid.: 307). According to the criteria included in the theory of Cas Mudde and Virág Molnár, these are the radically-right associations of civil society.

Table 1. Targets of Attacks by the Polish Radical Right (1989-2017)

\begin{tabular}{|l|l|l|}
\hline Politicians and international institutions & 37.3 percent & 359 events \\
\hline Ethnic and sexual minorities & 21.5 percent & 228 events \\
\hline
\end{tabular}

According to information from Płatek and Płucienniczak (ibid.)

The choice of targets clearly shows that this is a radically-right movement, which claims that it is the only real representative of the people betrayed by traditional elites and international institutions. Furthermore, according to the radical right, sexual and ethnic minorities undermine the ethical foundations and unity of the Polish nation. Who represents such an ideology? Who can be counted as civil associations of the Polish radical right? 


\section{Civic Associations of the Polish Radical Right}

According to an analysis by Płatek and Płucienniczak (2016), due to new and strong discursive opportunities, the civil society of the Polish radical right entered into a phase of its intensification and radicalisation after the parliamentary elections in 2007. Hence, their momentum coincided with the electoral victory of the Civic Platform (Platforma Obywatelska, PO), a moderate right party which combines economic liberalism and social conservatism, and is internally divided between a liberal and a conservative faction (Grzebalska, 2015). In that period, the main enemy of the radical right became the feminist and LGBT movements which, using the pro-Europeanness of the PO government, intensified their activities in the search for their rights. Since the promotion of traditional values was the main program of the radical right in that time, they presented the demands of the feminist and LGBT movements as the main threat to Polish families and nation. The protection of the latter served as justification to radical-right groups for attacks on homosexual pride parades and prochoice demonstrations. However, since 2012 those radical-right campaigns against its newfound enemies have taken the shape of a broad movement with clear aims and program. One of the main triggers that initiated the first anti-gender campaign in Poland was the public debate about the ratification of the Council of Europe's Convention on Preventing and Combating Violence against Women and Domestic Violence (the Convention) (Grzebalska, 2015; Szwed and Zielinska, 2017). It was Jarosław Gowin, the Minister of Justice in the Civic Platform (PO) government and the leader of the conservative faction in $\mathrm{PO}$, who brought the Convention to the wider public's attention in April 2012. He criticised the Convention calling it "a carrier of gender ideology" (Grzebalska, 2015). The Convention was also criticised by Polish Bishops' Conference (PBC), which found the fact that the Convention mentions the concept of gender unacceptable. According to PBC, the concept of gender implies that social roles are constructed, which negates "natural" differences between man and woman. Hence, the Church's officials saw the Convention as a threat to traditional family and a promotion of homosexuality (Szwed and Zielinska, 2017). These were the moments when the term "gender ideology" entered the public discourse in Poland. What followed was a three-year period of heated debate about gender.

During that time, many radical-right non-governmental organisations and initiatives emerged. Together with the Catholic Church, they have become the bearers of the struggle against "gender ideology", which now serves in anti-gender campaigns as a term for everything which threatens Polish children, the model of traditional Polish family, Christian civilisation, and consequently, the Polish nation. Anti-gender campaigns have mobilised thousands of people for demonstrations and civic initiatives, and created a network of various associations and groups that fight against a common enemy - "gender ideology". In that respect, it could be remarked that the Polish radical right succeeded in capturing a significant part of Polish civil 
society, and furthermore, succeeded to politicise certain topics and impose them on the public agenda. Anti-gender campaigns have also succeeded in building strong links between the Catholic Church, non-governmental organisations and politicians. As argued by Graff and Korolczuk, anti-genderism in Poland "proved remarkably effective in political terms, as it enabled a political alliance between nationalism and religious fundamentalism, thus contributing to the right-wing electoral victory of 2015" (Graff and Korolczuk, 2017: 1-2). Hence, authors point to a connection between the radical-right organisations' ability to impose their topics on the public agenda and the strategy of the Law and Justice party (Prawo i Sprawiedliwość, PiS) to present these topics as their own. PiS even addressed "gender ideology" in their party program from 2014, depicting it as a "foreign imposed threat to traditional family and national identity" (Grzebalska, 2015: 83). In that sense, the right-wing parts of Polish civil society played a significant role in bringing PiS to power in parliamentary elections in 2015.

In the following pages, we provide a brief description of the most prominent right-wing civic associations, their ideology and the actions they have carried out. They are presented as case studies which show how the anti-gender discourse originated from civic associations in the period between 2012 and 2015. Furthermore, these case studies also show how these organisations shared themes and campaigns, thus creating a strong network which gave them common purpose, a sense of community and movement. The criterion for the selection of these actors was not their size, but their prominence in the public sphere and the intensity of the debate about the topics they imposed. We do not claim the list of the main actors to be exhaustive, but they provide a representative sampling of the organisations and themes which dominated right-wing civil society in the examined period. The material for analysis consists of the content from radical-right organisations' web-pages and their statements available in the mass media. The material was analysed by means of qualitative content analysis.

\section{The Institute for Legal Culture Ordo Iuris}

One of the most influential right-wing associations in Poland is the Institute for Legal Culture Ordo Iuris. It was created in 2013 by the Association of Christian Culture Fr. Piotr Skarga. ${ }^{5}$ Ordo Iuris functions as a non-governmental organisation that acts in the form of a foundation. It is presented on its website as a think-tank that associates academics and legal practitioners who defend conservative values in the practice of applying the law. According to Ordo Iuris, "[e]very day people are

${ }^{5}$ It was founded in July 1999 in Krakow and was inspired by the world-renowned Association for the Defence of Tradition, Family and Property (TFP). 
confronted with various radical ideologies that aggressively question the existing social order. Such ideologies are not aimed at improving or healing society, but instead seek to destroy its very foundation" (Ordo Iuris, 2016). Guided by the idea of the legal order (ordo iuris), they believe that there is a "need for lawyers to become actively involved in the defence of the Constitution" (ibid.). Actually, their main activity is related to protection of provisions in the Constitution related to the protection of life from conception to natural death, marriage as a union of a man and a woman, the freedom of conscience and economic freedom. For example, when opposing the Convention on combating violence against women, their main arguments were that the Convention would be used to promote abortion (Ordo Iuris, 2014a) and that it contradicts a number of provisions of the Constitution of the Republic of Poland (Ordo Iuris, 2014b). Similar arguments were used against the Act on Infertility and the Act that regulates the issuance of 'day after' contraceptive pill EllaOne. The latter they treat as an abortion (Ordo Iuris, 2015a).

They also created two web-pages, www.protestuj.pl and www.maszwplyw.pl which serve as platforms for running social campaigns and for collecting signatures for protests, petitions, and social initiatives. They usually use these platforms to place pressure on institutions of the state, as in the case when they appealed to President Komorowski to send the Convention to review at the Constitutional Court (Protestuj, n.d.), to the Minister of Health Bartosz Arłukowicz for the immediate withdrawal from the Polish pharmaceutical market of EllaOne (Ordo Iuris, 2015b), and to the Ministry of Foreign Affairs to defend Poland against the abortion lobby at the UN (Maszwpływ, n.d.)! Ordo Iuris has also taken the leading role in criticising international institutions and documents. Beside the UN, the Council of Europe and the Convention on combating violence against women, most of their attacks have been directed towards the EU Parliament (Ordo Iuris, 2014c) and the EU in general. As argued by Ordo Iuris, "abortion lobbies or LGBT may have regarded the institutions of the European Union as the best place to promote their ideas beyond the real social control of ordinary citizens" (ibid.)

They also oppose 'sex education' in schools arguing that it is a form of indoctrination with gender ideology and an open violation of the well-being of children and the rights of parents to educate their children according to their own conviction" (Ordo Iuris, 2013). They also act as advocates of pro-life activists who refused to provide certain services by appealing to the conscience clause (Ordo Iuris, 2017). According to Ordo Iuris, by defending the right of conscience of healthcare professionals in Poland, they fight against the state's interference in this area of human life, which is fundamental for the identity of every Catholic. Hence, they present both cases as examples of inappropriate state intervention into citizens' private lives, which they compare to the communists' attempts to have full control over people's private and family life. 


\section{The Mom and Dad Foundation}

Another influential non-governmental organisation is The Mom and Dad Foundation (The Foundation). This foundation was established in Warsaw in May 2010. Their first action or campaign was an open letter called "The whole of Poland is protecting children". The letter appeared as a reaction to the European Gay and Lesbian Parade (EUROPRIDE) that took place in Warsaw in July 2010. In the letter, the Foundation states that "experiences of Western European countries show that the legalisation of the same-sex marriages is the first stage on the path to the adoption of children by homosexual couples" (Fundacja Mamy i Taty, 2010a). The Foundation believes that "gender ideology" and the "gay lobby" behind it represent the main threat to Polish children and families. One of the first reports released by the Foundation (October 2010) is a document titled "Against Freedom and Democracy: The Political strategy of the LGBT lobby in Poland and the world - goals, tools and consequences" (Fundacja Mamy i Taty, 2010b). According to the document, the aims of the "homosexual lobby" for the coming years are attempts to criminalise hate speech due to sexual orientation, the introduction of so-called sex education that is in accordance with the views of LGBT ideologists, equating same-sex relationships with marriage, and giving homosexual couples the right to unrestricted adoption of children (Fundacja Mamy i Taty, 2010c).

In June 2013, the Foundation organised an online petition to recall the Secretary of State, Agnieszka Kozłowska-Rajewicz. ${ }^{6}$ According to the Foundation, the "Secretary of State wants Polish children to be legally corrupted in schools and kindergartens by sexual educators with stories about homosexual relationships, about deviant forms of sexuality, and to be indoctrinated by the so-called right to abortion" (Prawy.pl, 2013). The Foundation sees the introduction of the program of sexual education as "another example of ideological attacks on the family, understood as a union of a man and a woman" (ibid.). At the beginning of March 2017, the association prepared the campaign "Mom, Daddy and Kid" which fights for "national laws to have the primacy over European law. In practice this means that Brussels will not be able to impose on Warsaw the legalisation of homosexual marriages and adoption by lesbian and gay couples" (Fundacja Mamy i Taty, 2017).

In 2016, the Foundation organised a social campaign entitled "Don't Postpone Motherhood Until It's Too Late", part of which is the video that shows a successful and wealthy middle-aged woman who regrets not having children. In the video she says: "I managed to have a career and to become a specialist; to see Tokyo and

${ }^{6}$ She served for three years as Secretary of State in the Prime Minister's Chancellery as Government Plenipotentiary for Equal Treatment. She also served as a member of the Council for the Prevention of Racial Discrimination, Xenophobia and Related Intolerance. 
Paris; to buy an apartment and renovate the house. But I did not become a mother. And I'm sorry for that" (Nie odkładaj macierzyństwa na potem, n.d.). The video ends with the woman in tears. Grzebalska correctly notes that the video clearly suggests that the problem of extremely low birth rates in Poland is in female egoism, i.e. in wrongly understood gender roles. On the other hand, it does not touch other, perhaps more objective reasons why women today postpone or do not want maternity, such as financial instability or insufficient provision of state-funded childcare (Grzebalska, 2016).

\section{Foundation Pro-Right to Life}

One of the key anti-abortion organisations is the Foundation Pro-Right to Life. This foundation organised the legislative initiative "Stop abortion", which has the goal of initiating a total ban on abortion in Poland. In the last decade, they succeeded in collecting more than 100,000 signatures $^{7}$ several times and sending their proposal to the Sejm (the lower house of the Polish Parliament). In 2011, they collected over 600,000 signatures. The goal was to introduce a total ban on abortion and imprisonment for performing one. The sentence ranged from three months to five years for a person performing the procedure, and even 10 years for those who would force a woman to terminate her pregnancy. The civic anti-abortion bill was rejected by the Sejm, but it lacked only 5 votes in order to pass. The initiative was supported by the Catholic Association of Polish Physicians (Katolickie Stowarzyszenie Lekarzy Polskich, n.d.). The same Initiative was organised in 2013, 2014, 2015 and 2016 - each time collecting the necessary signatures. Each time, the anti-abortion bills were rejected by the Sejm.

In the Statute of the Foundation, it is stated that their most important goals are to protect human life from the moment of conception to natural death, strengthen the position of the family as the basis of social relations, support the institution of marriage as a way to happiness, and support parenting through activities in the field of education, culture and science (Fundacja Pro - Prawo do Życia, n.d.). It is stressed on their website that they have already organised 1,293 demonstrations, 232 pro-life exhibitions and 135 training sessions across Poland. They are organised in such a way that they have built a network of more than 60 cells all over Poland. When recruiting members, they offer options to act online and offline and encourage visitors to visit their site and build a cell in their area (ibid.).

7 According to the Polish law, initiatives of that sort have to collect at least 100,000 signatures in order to be received by the Sejm. 


\section{The Centre for Supporting Initiatives for Life and Family}

The Centre for Supporting Initiatives for Life and Family (The Centre) is an organisation that organises The March for Life and Family, an annual march which serves as a meeting of all significant pro-life, pro-family and anti-gender organisations. The March for Life and Family promotes family values, especially marriage - understood as a relationship between a woman and a man - and respect for life from conception to natural death. The first march took place on June 4, 2006 in Warsaw and was attended by 2,000 people. Through the years, the March has grown and in 2012 it took place in 40 Polish cities with tens of thousands of participants. In 2013, the Centre together with other groups involved in the organisation of the marches issued a Declaration of March for Life in which they declare that "Poland needs a change... a new order which should be based on respect for human life and the recognition of the family as the central institution of the social order" (Centrum Życia i Rodziny, 2018). According to the Centre, for the longest time, respect for life and family have represented fundamental truths underlying our civilisation and the existing social order. They believe that these truths are increasingly under attack by promoters of the so-called "civilisation of death" and "dictatorship of relativism". For that reason, they undertake actions and support initiatives that provide support to doctors calling for a conscience clause, oppose contraception, fight for the rights of parents and the rights of unborn children, and carry out child protection campaigns against LGBT propaganda (Centrum Wspierania Inicjatyw dla Życia i Rodziny, n.d.).

\section{Catholic Professional Associations}

Finally, there are also professional associations that could be considered part of "the classical liberal, free professions" (Molnár, 2016) that carry the Catholic prefix. There is, for example, the Catholic Association of Physicians, the Catholic Association of Educators, the Catholic Association of Journalists, and the Association of Catholic Pharmacists. All of these associations have declared that their commitment to Catholic values comes before the regulations and norms of their professions.

In the spring of 2014 , during the $90^{\text {th }}$ pilgrimage of Polish doctors to Częstochowa, three thousand doctors came together in Jasna Góra Monastery and announced the Declaration of Faith. The Declaration is engraved on the stone tablets and has remained at Jasna Góra as a token of gratitude for canonization of John Paul II. The document was written and the engraving initiated by Wanda Półtawska, a doctor known for her long friendship with Karol Wojtyła. In the document, the doctors express their Catholic faith and commit themselves to protecting human life from its conception. They wrote that they "recognize the priority of God's law over human law" and express the need "to oppose the imposed antihumanitarian 
ideologies of modern civilisation" (Deklaracja Wiary, n.d.). According to the document, "the moment of conception and descent from this world depends solely on the decision of God. If the decision is made by man, committing acts such as abortion, contraception, artificial insemination, euthanasia, in vitro fertilization, he violates not only the Ten Commandments but rejects the Creator himself" (ibid.). Hence, the main message of the document is that God's law has priority over human law and that the Catholic faith is more important than fulfilling the needs of patients. In 2014, the "Declaration of Faith and Conscience of Polish Teachers" was initiated by blogger Janusz Górzański, who describes himself as a "Catholic-Nationalist Polish Monarchist". In the Declaration, he states that "I, teacher of the Polish Republic, commit to educate and teach young generations of Poles in the spirit of love for truth and, above all, love for God's truth" (Gazeta Wyborcza, 2014). Some pharmacists also followed the doctors' and teachers' examples and have also demanded a conscience clause, which would allow them to refuse to sell prescribed contraceptives (Grabowska, 2015). These organisations of physicians, pharmacists, teachers and journalists, together with lawyers from Ordo Iuris show how associations of classical liberal free professions also take part in the formation of anti-liberal ideas and the rise of right-wing radicalism.

\section{Discussion}

As we see from these case studies, the concept of "gender ideology" is at the centre of radical-right mobilisations in Poland. Namely, the fight against "gender ideology" is not a Polish invention. The whole story started after the 1994 International Conference on Population and Development in Cairo and the 1995 Fourth World Conference on Women in Beijing. It was the Vatican who immediately opposed the feminist use of the term gender in documents accompanying these Conferences. Since then, the fight against the "gender ideology" has become one of the main occupations of the Vatican. In their struggle, the emphasis is on the imperative to influence secular law and policy in line with their vision of society (Case, 2011). Their main strategy is to present the right to life as a political problem, where "life" encompasses virtually everything related to the family, human sexuality, and bioethics. This is the reason why they, besides abortion, cover issues from sex education to the social roles of women. In these efforts, the Vatican is backed by various civic associations of the Catholic laity which play a crucial role in national and international lobbying for the Vatican (Urquhart, 2014). As a rule, these anti-abortion and defence-of-the-family activists present themselves as grass root initiatives of concerned parents and citizens who exercise their democratic right. As shown by Urquhart, it is often the case that the main actors of anti-gender campaigns are very influential figures who belong to national and international associations, with which 
the Vatican also works at the organisational level (ibid.). They are internationally very well connected and financed. These associations have mushroomed all over Europe in the last decade, mobilising citizens in the defence of the "Civilisation of Life" against the "Culture of Death". According to Peto,, what is really at stake here is an attempt to redefine human rights and the European tradition of equality (Petö, 2015).

As shown by our analysis of Polish anti-gender associations, the common denominator of all these organisations is that they draw on Catholic social teaching and moral values. Their overall goal is to influence the decision-making process of government in order to enshrine/implement values and principles of Catholic social teaching into the Polish legal system. According to Catholic social teaching, the basis and the final purpose of society should be the person. Two natural communities in which the person can flourish are family and nation, and as such, they should be promoted and protected (Weiler, 1995). In the case of the Polish radical right, what happened is a particular reading or interpretation of Catholic social teaching in which the means has become the goal, i.e. the nation becomes the final and ultimate value. In this respect, this interpretation enables a fusion between ethnonationalism and Catholicism. Furthermore, a special role in this vision is dedicated to family which is understood as basic constituent of the nation. Hence, it is family and not the individual that is understood as the basic entity of society and the carrier of rights, thus contradicting the liberal democratic emphasis on the significance of individual inviolable rights.

This illiberal and anti-pluralist vision of society also finds its legitimation within Polish national tradition, which is one of the main reasons why it resonates very well among certain segments of the Polish public. The image of a Polish nation as fundamentally Catholic is derived from Polish national mythology, which serves as an important ingredient of Polish cultural resources. Here we refer to two particular myths, the one about Poland as the Bulwark of Christendom, the antemurale christianitatis, and the myth of the 'Catholic Pole' (Polak-Katolik), the essence of which is the belief that only a Roman Catholic qualifies as a 'real Pole' (Davies, 1997). The idea immanent in the first myth is that there is a special role assigned to the Polish nation not only to protect Christianity and Christian civilisation, but also to spread its ideas and values. Faith in this particular, messianic role often results in the feeling of righteous dedication and the moral superiority of the Polish nation. The second myth was transferred into a political concept by Roman Dmowski (1870-1930) and became a fundamental part of his 'National Democracy' (Stronnictwo narodowe), a nationalist political movement in the interwar period (Walicki, 2000). As an opposition to 'Real' or 'Catholic Poles', Dmowski constructed the concept of 'Half-Poles', defined as 'individuals, who despite their Polish culture, 
assume a neutral and objective stand in the confrontations between Poles and nonPoles, thereby proving that they lack a deep moral bond with their compatriots, that they see the nation not as an organic whole, but merely as a loose congregation of individuals, groups and classes" (ibid.). Finally, it was Cardinal Stefan Wyszyński (1901-1981) ${ }^{8}$ who developed a concept of Polish nation that integrated various components of Polish nationalism which all 'witness' the inextricable connections between Polishness and Catholicism. For Cardinal Wyszyński, the nation was an "organic community" which is constituted of families and common land (Zubrzycky, 2006). His quotes are very popular among right-wing civic associations and are often shared through their social media, especially the one about "the nation as a family of families" (Fronda.pl, n.d.).

It is within this clerical-nationalist framework with its cultural references that the Polish radical rights' mobilisation against gender should be understood. In their view, the nation presents the highest value and ultimate goal of their activities. The role of the state is to protect traditional family (with a strict distribution of gender roles) and life from the moment of conception, since only newborns raised in a 'normal' Polish family could guarantee the persistence and healthiness of the Polish nation. Hence, women are primarily perceived as having a special role of biological reproducers and "bearers of culture" (Graff, 2009), and not as persons having the right to pursue their lives according to their choices. Following this logic, it is women's reproductive rights and gender roles that become the main battlefield for the Polish radical right. In their view, since women play a crucial role for the destiny of the nation, their liberally understood rights should be trumped by the interest of the nation. On the other hand, from the radical-right point of view, homosexuals represent the significant 'Other', an alien who threatens 'us' with his sexual practices and forms of lives which are not of 'our kind'. Moreover, their strategy consists of turning sexual minorities into a type of pathological ailment by constantly using terms such as 'deviants' or 'perverts' in reference to sexual minorities (Shibata, 2009). Hence, homosexuality is presented as a disease which threatens the Polish family, thus representing one of the main enemies of the nation. What should be promoted and protected is home-grown natural heterosexuality (Graff, 2009).

Therefore, by insisting on the protection of the traditional model of the Polish family, the right-wing associations in Poland claim to protect the essence of the Polish nation and Christian civilisation as a whole. The starting point and the main reason of their activity is a diagnosis of social life according to which the tradi-

${ }^{8}$ Polish archbishop of Gniezno and Warsaw and primate of Poland during the communist period. He was an intimate friend of John Paul II, and often called 'the Primate of the Millennium' in Poland. 
tional family is under attack and disdained. In their words, their common enemy is "gender ideology" and the "LGBT lobby" behind it, together with all those leftists and liberals in Poland and abroad. "Gender ideology" threatens the family and the nation at the biological level - abortion, contraception, IVF, homosexual relationships - and at the symbolic level - the removal of Christian values from education, the public sphere in general, and from the process of legislation (Szwed and Zielinska, 2017: 124). However, while promoting the traditional family as an ideal and basic unit of society, they treat minorities together with a pluralism of views and lifestyles as disruptive factors of national harmony. This premise is supported by Pető (2015) and Grzebalska (2016) who claim that anti-gender mobilisation is only a coverup for fostering fundamental changes in the European political and value system. Hence, anti-genderism is not "just" a feminist issue, but rather one threatening the basic principles of European liberal democracy. Regarding the last point, it follows that gender should not be conceptualised as the central point of this mobilisation, at least in the Polish case. What is really at stake here is these groups' fight against the liberal democratic state and its values.

Namely, "gender ideology" is presented as non-Christian, thus alien to the Polish culture and nation. This is the moment where the radical right employs the antemurale christianitatis myth, presenting themselves as the true defenders of authentic Polish culture and indigenous values from ideas and values imported by the decadent West. The main narrative claims that both feminism and homosexuality are imported from the West in order to undermine true Polishness. According to Graff and Korolczuk (2017), it is about the strategy of employment of the anti-colonial, Eurosceptic discourse which constructs the image of international institutions such as the UN, the EU and WHO as cultural colonisers, threatening the Polish national culture and corrupting innocent Polish children. As shown in our analysis, it is the EU that is particularly demonised and presented as a colonial power. Basically, what the Polish radical right truly claims is that the values on which EU architecture is constructed are not Polish values.

Moreover, Polish national institutions like the Government, the President, the Parliament, judiciary, media and liberal parts of Polish civil society are presented as EU agents and 'Half-Poles' who have betrayed their country and who are participating in a global plot against Poland, its culture and identity. As shown in the cases related to sex education and the conscience clause, they are disqualified not only as an imposition of the liberal West, but also as remnants of communist practices. By taking this perspective they present liberal values as some kind of communist leftovers. Basically, radical-right associations are delegitimising institutions of the Polish state, especially those that serve as checks and balances to executive power or the rule of the majority. Furthermore, by insisting on moral issues, radical-right 
associations polarise political space by presenting themselves as the single defenders of the Polish nation and family, demonising everybody who opposes them. By reducing politics to the friend-enemy relationship, they undermine the basic principles of the liberal democratic system.

\section{Conclusion}

This analysis of the Polish radical right has shown that its discourse is pronouncedly anti-liberal. The main targets of their attacks are minority and women's rights, or rather the right to individual sexual orientation and the freedom of choice about giving birth. Their anger is also focused at the autonomous institutions of the Polish state, primarily judicial and educational institutions. The radical right thus wants control over judicial decisions and educational programmes. In other words, they are trying to subject public life as a whole to Catholic dogmas that, according to their opinion, represent the unchanging foundation of Polish national identity. Although their propaganda attacks the party system by appealing to the supposedly fundamental values of the Polish nation, in practice they support the ruling party, Law and Justice because they believe they can use it to achieve their mission.

With their attacks on politics and attempts to substitute the work of political institutions, radical-right associations within civil society essentially weaken democracy. Namely, conflicts cannot be resolved at the societal level, but through political negotiations between parties that have been provided by parliamentary procedure. Moralising, which is often advocated by civil society associations, stands in the way of achieving a compromise, and it is precisely compromise that is the essence of democratic politics. Compromise can be reached if conflict is transferred from the level of society to that of politics, where it can be managed within competent political institutions and according to the stipulated procedure. The endeavour to replace government institutions with society, or rather NGOs, therefore implies the destruction of democracy, even if there is a sincere desire to strengthen it. Liberal-democratic order was historically and systemically designed for the state, and it cannot be built in the absence of clearly structured and strong democratic political institutions. Democracy is not possible without a functioning parliament, parties and courts. Civil organisations can contribute to the work of these institutions, but they cannot replace them. Therefore, even though civil society has played an emancipatory role in "real socialism" and used its "anti-political politics" (Vaclav Havel) to establish a space free from a one-party state and dictatorship, today its attacks on government institutions are capable of crippling the development of democracy. 


\section{REFERENCES}

Armony, C. Ariel. 2004. The Dubious Link. Civic Engagement and Democratization. Stanford University Press. Stanford.

Berman, Sheri. 1997. Civil Society and the Collapse of the Weimar Republic, World Politics, (49) 3: 401-429.

Bergmann, Werner. 1994. Ein Versuch, die extreme Rechte als soziale Bewegung zu beschreiben (An attempt to describe extreme right as social movement), in: Werner Bergmann and Rainer Erb (eds.): Neonazismus und rechte Subkultur. Metropol. Berlin: 183-207.

Bežovan, Gojko and Jelena Matančević. 2017. Civilno društvo i pozitivne promjene. (Civil Society and Positive Changes). Školska knjiga. Zagreb.

Boban, Ljubo. 1974. Maček i politika Hrvatske seljačke stranke 1928-1941.: iz povijesti hrvatskog pitanja. (Maček and Politics of Croatian Peasants Party 1928-1941.: from History of the Croatian Question), Vol. 1. Liber. Zagreb.

Case, Mary Anne. 2011. After Gender the Destruction of Man? The Vatican's Nightmare Vision of the "Gender Agenda" for Law, Pace Law Review, (31) 3: 802-817.

Centrum Wspierania Inicjatyw dla Życia i Rodziny. n.d. “O nas”, at http://czir.org/o-nas/ (accessed 1 May 2018).

Centrum Życia i Rodziny. 2018. At http://marsz.org/o-nas/ (accessed 1 May 2018).

Cipek, Tihomir. 2017. The Spectre of Communism Is Haunting Croatia, Politička misao, (54) 1-2: 150-169.

Davies, Norman. 1997. Polish National Mythologies, in: Geoffrey Hosking and George Schöpflin (eds.): Myths and Nationhood. Routledge. New York: 141-157.

Deklaracja Wiary. n.d. At http://racjonalista.tv/o-deklaracji-wiary/?print=pdf (accessed 1 May 2018).

Eatwell, Robert. 1996. On defining the "Fascist Minimum": The centrality of ideology, Journal of Political Ideologies, (1) 3: 303-319.

Fronda.pl. n.d. "Prymas Wyszyński: Naród jest rodziną rodzin" (Cardinal Wyszyński: Nation is a family of families), at http://www.fronda.pl/a/prymas-wyszynski-narodjest-rodzina-rodzin,84812.html (accessed 1 May 2018).

Fundacja Mamy i Taty. 2010a. "Cała Polska chroni dzieci!” (Whole Poland is Defending Children!), at http://www.mamaitata.org.pl/wiadomosci/cala-polska-chroni-dzieci (accessed 10 May 2018).

Fundacja Mamy i Taty. 2010b. "Przeciw wolności i demokracji. Strategia polityczna lobby LGTB w Polsce i na świecie: cele, narzędzia, konsekwencje" (Against liberty and democracy: political strategy of LGBT lobby in Poland and the world: goals, tools and consequences), at http://www.mamaitata.org.pl/gfxupload/pliki/ Przeciw_wolnosci_i_demokracji__Raport_Fundacji_Mamy_i_Taty.pdf (accessed 8 May 2018). 
Fundacja Mamy i Taty. 2010c. "Przeciw wolności i demokracji" (Against freedom and democracy), at http://www.mamaitata.org.pl/raporty/przeciw-wolnosci-i-demokracji (accessed 1 May 2018).

Fundacja Mamy i Taty. 2017. Facebook, March 11, 2017, at https://www.facebook.com/ FundacjaMamyiTaty/posts/1656969030985444 (accessed 15 May 2018).

Fundacja Pro - Prawo do Życia. n.d. At https://stopaborcji.pl/ (accessed 1 May 2018).

Gazeta Wyborcza. 2014. At http://wyborcza.pl/1,76842,16395954,Kluzik_Rostkowska_Klauzula_sumienia_dla_nauczycieli.html\#ixzz3AAJAf7mD (accessed 1 May 2018).

Giza-Poleszczuk, Anna. 2017. (Mis)understanding Social Activism in Poland, in: Kerstin Jacobsson and Elżbieta Korolczuk (eds.): Civil Society Revisited. Lessons from Poland. Berghahn. New York-Oxford: 63-80.

Grabowska, Magdalena. 2015. Cultural War or Business as Usual? Recent Instances and the Historical Origins of the Backlash Against Women's Rights and Sexual Rights in Poland, in: Aghdgomelashvili, Ekaterine et al. (eds.): Anti-Gender Movements on the Rise? Heinrich Böll Stiftung. Warsaw: 54-64.

Graff, Agnieszka. 2009. Gender, Sexuality, and Nation - Here and Now: Reflections on the Gendered and Sexualized Aspects of Contemporary Polish Nationalism, in: Oleksy, Elzbieta H. (ed.): Intimate Citizenship. Gender, Sexualities, Politics. Routledge. New York and Oxford: 133-146.

Graff, Agnieszka, and Elżbieta Korolczuk. 2017. Worse than communism and nazism put together: War on Gender in Poland, in: Kuhar, Roman and David Paternotte (eds.): Anti-Gender Campaigns in Europe: Mobilizing Against Equality. Rowman \& Littlefield International. London and New York: 175-194.

Grzebalska, Weronika. 2015. Poland, in: Kovats, Eszter and Maari Poim (eds.): Gender as Symbolic Glue. The Position and Role of Conservative and Far Right Parties in the Anti-Gender Mobilizations in Europe. Friedrich Ebert Stiftung. Berlin: 83-103.

Grzebalska, Weronika. 2016. "Why the war on 'gender ideology' matters - and not just to feminists. Anti-genderism and the crisis of neoliberal democracy", at http:// visegradinsight.eu/why-the-war-on-gender-ideology-matters-and-not-just-to-feminists/ (accessed 26 May 2018).

Hillmann, Karl-Heinz. 2007. Wörterbuch der Soziologie (Dictionary of Sociology). Alfred KörnerVerlag. Stuttgart ( $5^{\text {th }}$ edition).

Hočevar, Marko and Igor Lukšič. 2018. Razmerje med hegemonijo in ideologijo v Gramscijevi politični teoriji (Relationship Between Theory and Practice in Gramsci Political Theory), Teorija in praksa, (55) 1: 6-26.

Katolickie Stowarzyszenie Lekarzy Polskich. n.d. At http://kslp.pl/walka-o-ochronezycia-ludzkiego/stanowisko-katolickiego-stowarzyszenie-lekarzy-polskich-wsprawie-stosunku-do-zycia-ludzkiego/ (accessed 1 May 2018). 
Koopmans, Ruud and Paul Statham. 1999. Political Claims Analysis: Integrating Protest Event and Political Discourse Approaches, Mobilization: An International Quarterly, September, (4) 2: 203-221.

Kovács, M. Mária. 1994. Liberal Professions and Illiberal Politics: Hungary from the Habsburgs to the Holocaust. Front Cover. Woodrow Wilson Center Press. Washington.

Lipset, Seymour and Earl Raab. 1970. The Politics of Unreason: Right Wing Extremism in America, 1790-1970. Harper and Row. New York.

Maszwpływ. n.d. At http://www.maszwplyw.pl/-wezwij-msz-do-obrony-polski-przeddyktatem-lobby-aborcyjnego-w-onz,49,k.html (accessed 1 May 2018).

Minkenberg, Michael. 2000. The Renewal of the Radical Right: Between Modernity and Anti-modernity, Government and Opposition, (35) 2: 170-188.

Minkenberg, Michael. 2015. Transforming the Transformation? The East European Radical Right in the Political Process. Routledge. London.

Molnár, Virág. 2016. Civil society, radicalism and the rediscovery of mythic nationalism, Nations and Nationalism, (1): 165-185.

Mudde, Cas. 2003. Civil Society in Post-Communist Europe. Lessons From the "Dark Side", in: Petr Kopecky and Cas Mudde, Uncivil Society? Contentious Politics in Post-Communist Europe. Routledge. London: 1-18.

Mudde, Cas. 2004. The Populist Zeitgeist, Government and Opposition, (39) 4: 541-563.

Mudde, Cas. 2007. Populist Radical Right Parties in Europe. Cambridge University Press. Cambridge.

Mudde, Cas. 2010. The Populist Radical Right: A Pathological Normalcy, West European Politics, (33) 6: 1167-1186.

Nie odkładaj macierzyństwa na potem. n.d. At http://www.nieodkladajmacierzynstwa.pl/ (accessed 1 May 2018).

Oberländer, Erwin (ed.). 2017. Autoritäre Regime in Ostmittel- und Südosteuropa 19191944. (Authoritarian Regimes in East-Central and South Europe). Schöningh. Paderborn.

Orban, Viktor. 2014. At https://budapestbeacon.com/full-text-of-viktor-orbans-speechat-baile-tusnad-tusnadfurdo-of-26-july-2014/ (accessed 26 April 2018).

Ordo Iuris. 2013. At http://ordoiuris.pl/rodzina-i-malzenstwo/gender-obowiazkowo-wszkolach-pytania-do-rady-europy (accessed 12 May 2018).

Ordo Iuris. 2014a. At http://ordoiuris.pl/rodzina-i-malzenstwo/czy-konwencja-re-oprzeciwdzialaniu-przemocy-wobec-kobiet-bedzie-sluzyc (accessed 26 April 2018).

Ordo Iuris. 2014b. At http://ordoiuris.pl/rodzina-i-malzenstwo/stanowisko-ordo-iurisws-ratyfikacji-konwencji-rady-europy-w-sprawie (accessed 26 April 2018).

Ordo Iuris. 2014c. At http://ordoiuris.pl/rodzina-i-malzenstwo/rezolucja-lunacek-parlament-europejski-poparl-tworzenie-przywilejow-dla (accessed 1 May 2018). 
Ordo Iuris. 2015a. At http://ordoiuris.pl/ochrona-zycia/rozporzadzenie-dopuszczajacewydawanie-ellaone-bez-recepty-narusza-przepisy (accessed 21 April 2018).

Ordo Iuris. 2015b. At http://ordoiuris.pl/ochrona-zycia/apel-do-ministra-zdrowia-o-wycofanie-preparatow-zawierajacych-octan-uliprystalu (accessed 1 May 2018).

Ordo Iuris. 2016. "Who we are?", at http://en.ordoiuris.pl/who-we-are (accessed 26 April 2018).

Ordo Iuris. 2017. "Ordo Iuris. Institute for Legal Culture”, at https://ipco.org.br/wp-content/uploads/2017/10/Ordo-Iuris-eng.pdf (accessed 15 May 2018).

Ost, David. 2006. Defeat of Solidarity. Anger and Politics in Postcommunist Europe. Cornell University Press. Ithaca.

Pankowski, Rafał. 2010. The Populist Radical Right in Poland: The Patriots. Routledge. London.

Pető, Andrea. 2015. Epilogue: “Anti-Gender" Mobilisational Discourse of Conservative and Far Right Parties as a Challenge for Progressive Politics, in: Kovats, Eszter and Maari Poim (eds.): Gender as Symbolic Glue. The Position and Role of Conservative and Far Right Parties in the Anti-Gender Mobilizations in Europe. Friedrich Ebert Stiftung. Berlin: 126-131.

Platek, Daniel and Piotor Plucienniczak. 2017. Mobilizing on the Extreme Right in Poland: Marginalization, Institutionalization, and Radicalization, in: Kerstin Jacobsson and Elżbieta Korolczuk (eds.): Civil Society Revisited. Lessons from Poland. Berghahn. New York-Oxford: 286-313.

Prawy.pl. 2013. At http://prawy.pl/3216-podpisz-apel-odwolajmy-kozlowska-rajewiczza-seksualizacje-dzieci/ (accessed 1 May 2018).

Protestuj. n.d. At http://www.protestuj.pl/konwencja-do-trybunalu---zaapeluj-do-prezydenta,37,k.html (accessed 1 May 2018).

Putnam, D. Robert et al. 1994. Making Democracy Work: Civic Traditions in Modern Italy. Princeton University Press. Princeton.

Riley, Dylan. 2010. The Civic Foundations of Fascism in Europe: Italy, Spain and Romania 1870-1945. Verso. London.

Rupnik, Jacques. 2007. Is East-Central Europe Backsliding? From Democracy Fatigue to Populist Backlash, Journal of Democracy, (18) 4: 17-25.

Scheuch, Erwin and Hans-Dieter Klingemann. 1967. Theorie des Rechtsradikalismus in westlichen Industriegesellschaften (Theory of right radicalism in western industrial societies), Hamburger Jahrbuch für Wirtschafts- und Gesellschaftspolitik, Vol. 12: 11-29.

Shibata, Yasuko. 2009. The Fantasmic Stranger in Polish Nationalism: Critical Discourse Analysis of LPR's Homophobic Discourse, Polish Sociological Review, 166: 251271. 
Szwed, Anna and Katarzyna Zielinska. 2017. A War on Gender? The Roman Catholic Church's Discourse on Gender in Poland, in: Ramet, Sabrina and Irena Borowik (eds.): Religion, Politics, and Values in Poland. Continuity and Change Since 1989. Palgrave Macmillan US. New York: 113-136.

Šalaj, Berto. 2012. Civilno društvo i demokracija: što bi Tocqueville i Putnam vidjeli u Hrvatskoj? (Civil society and democracy: what would Tocqueville and Putnam see in Croatia), Anali Hrvatskog politološkog društva, (8) 1: 49-71.

Urquhart, Gordon. 2014. "The Vatican and Family Politics. Conservative Catholic Influence in Europe", at http://www.catholicsforchoice.org/wpcontent/uploads/2014/01/ vaticanandfamilypolitics.pdf (accessed 26 April 2018).

Walicki, Andrzej. 2000. The Troubling Legacy of Roman Dmowski, East European Politics and Societies, (14) 1: 12-46.

Wehler, Hans-Ulrich. 2003. Deutsche Gesellschaftsgeschichte. Vom Beginn des Ersten Weltkriegs bis zur Gründung der beiden deutschen Staaten 1914-1949. (History of German Society: From the Beginning of the First World War to the Founding of the Two German States 1914-1949), vol. 4. Beck. München.

Weiler, Rudolf. 1995. Uvod u katolicki socijalni nauk (Introduction into Catholic Social Teaching). Školska knjiga. Zagreb.

Weiß, Volker. 2017. Die autoritäre Revolte. Die "Neue Rechte" und der Untergang des Abendlandes (Authoritarian Revolt. "New Right" and the Fall of the West). KlettCotta. Stuttgart.

Wodak, Ruth. 2015. The Politics of Fear: What Right-Wing Populist Discourses Mean. Sage. London.

Zgurić, Borna. 2014. Stranke radikalne desnice: mađarski Jobbik i nizozemska Slobodarska stranka (Radical right parties: Hungarian Jobbik and the Dutch Party for Freedom), Politička misao, (51) 4: 90-113.

Ziegler, Dezso Tamas. 2018. The Populist Hoax - Getting The Far Right and Post-Fascism Wrong, Social Europe, at https://www.socialeurope.eu/the-populist-hoax-getting-the-far-right-and-post-fascism-wrong (accessed 2 February 2018).

Zubrzycki, Genevieve. 2006. The Crosses of Auschwitz. Nationalism and Religion in Post-Communist Poland. The University of Chicago Press. Chicago and London.

Mailing Addresses:

Tihomir Cipek, Professor of Croatian Politics, Faculty of Political Sciences, University of Zagreb, Lepušićeva 6, 10000 Zagreb.E-mail: tihomir.cipek@fpzg.hr Stjepan Lacković, PhD Student in Comparative Politics, Faculty of Political Sciences, University of Zagreb, Lepušićeva 6, 10000 Zagreb. E-mail: stjepanlackovic@yahoo.com 